Al Qalam: Jurnal Ilmiah Keagamaan dan Kemasyarakatan

https://jurnal.stiq-amuntai.ac.id/index.php/al-qalam

P-ISSN: 1907-4174; E-ISSN: 2621-0681

DOI : 10.35931/aq.v16i2. 923

\title{
IMPLEMENTASI KEGIATAN SHOLAT TAHAJUD DALAM MENINGKATKAN KEDISIPLINAN SANTRI DI PONDOK PESANTREN PUTRI BABUSSALAM BANJAREJO PAGELARAN MALANG
}

\author{
ALIF ACHADAH \\ Universitas Islam Raden Rahmat Malang \\ achadahalif@gmail.com \\ Fina Faza Rohmah \\ Universitas Islam Raden Rahmat Malang \\ finavasarohmah@gmail.com
}

\begin{abstract}
Abstrak
Penelitian ini dilatar belakangi oleh pentingnya pembiasaan dalam membentuk kepribadian anak agar memiliki kepribadian yang berakhlaqul karimah. Jenis penelitian yang digunakan adalah metode deskriptif kualitatif dan pendekatan fenomenologi, dengan jenis penelitian lapangan. Teknik analisis data menggunakan teknik analisi data deskripsi kualitatif dengan langkah: pengumpilan data, reduksi data, penyajian data, menarik kesimpulan atau verifikasi. Hasil penelitian ini menunjukkan bahwa pelaksanaan kegiatan sholat tahajud di Asrama Tahfidzul Qur'an Pondok Pesantren Babussalam berjalan dengan lancar sehingga dapat memberikan pengaruh terhadap pembentukan kepribadian santri yang disiplin dan berakhlaqul karimah. Pelaksanaan kegiatan sholat tahajud di Asrama Tahfidzul Quran Pondok Pesantren Babussalam dilaksanakan pada pukul 03.00 hingga selesai. Pelaksanaan sholat tahajud dilaksanakan secara berjamaah oleh para santri dan setelah selesai melaksanakan sholat tahajud dilanjutkan para santri melaksanakan kegiatan muroja'ah hafalan bersama yang mana kegiatan murojaah ini dipimpin oleh para pengawas. Implikasi kegiatan sholat tahajud dapat menambah ketaqwaan kepada Allah SWT, meningkatkan kedisiplinan waktu, kedisiplinan tingkah laku, merasakan ketenangan jiwa, meningkatkan motivasi belajar santri. Faktor pendukung pelaksanaan kegiatan sholat tahajud adalah adanya kerjasama para santri, adanya hukuman bagi santri yang melanggar, dan pemberian penghargaan bagi santri yang aktif, teladan dan kamar teladan, faktor penghambat pelaksanaan kegiatan sholat tahajud merupakan tergolong kendala kecil seperti kemalasan santri dan kurang aktifnya santri

Kata kunci: Implementasi, kegiatan sholat tahajjud, kedisiplinan santri.
\end{abstract}

\section{PENDAHULUAN}

Pada zaman yang serba berkembang seperti saat ini sangatlah diperlukan adanya sikap disiplin yang hal tersebut dapat menunjang dalam mencapai keberhasilan yang diinginkan. Perilaku disiplin haruslah dikembangkan oleh murid / peserta didik / santri karena dengan adanya kedisiplinan dalam diri seseorang sebagai kontrol dari dalam diri dalam berperilaku mentaati

Al Qalam: Jurnal Ilmiah Keagamaan dan Kemasyarakatan Vol. 16, No. 2 Maret - April 2022 
Alif Achadah, Fina Faza Rohmah : Implementasi Kegiatan Sholat Tahajud Dalam Meningkatkan Kedisiplinan Santri di Pondok Pesantren Putri Basussalam Banjarejo Pagelaran Malang

peraturan yang ada sesuai dengan norma yang berkembang di masyarakat. ${ }^{1}$ Sikap disiplin dapat dikatakan disiplin dalam beribadah, disiplin dalam belajar, disiplin dalam mentaati peraturan sekolah, dan lain-lain.

Kedisiplinan yang dimiliki oleh seseorang hendaknya akan menjadi pondasi yang kuat agar tidak terjerumus pada hal - hal dan perilkau negative yang dapat merusak moral. Disiplin adalah sebuah sikap taat yang sangat yang dalam melakukannya atas dasar kesadaran dalam rangka menjalankan kewajiban serta tanggung jawab dalam kondisi atau lingkungan tertentu yang terikat oleg peraturan dan norma tertentu. ${ }^{2}$

Implementasi kedisiplinan perlu adanya peraturan yang legal terkait dengan kedisiplinan yang dilakukan. Peraturan setidaknya dibuat untuk ditaati untuk mengatur perilaku manusia sehingga dapat menjadikan kehidupan lebih baik. Sehingga dalam Islam mengatur keberadaan perilaku disiplin seperti dalam penerapan ibadah sholat, belajar, mencari nafkah, dan lain-lain. Dalam ayat al-qur'an juga menjelaskan tentang petunjuk manusia agar menghargai waktu yang terdapat dalam surah Al-Ashr 1-3 yaitu :

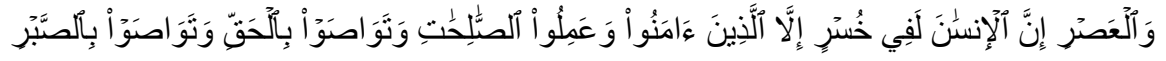

Artinya: "Demi masa (1) sungguh, manusia berada dalam kerugian (2) kecuali orangorang yang beriman dan mengerjakan kebajikan serta saling menasihati untuk kebenaran dan saling menasihati untuk kesabaran (3)". ${ }^{3}$

Dalam ayat tersebut diketahui bahwa manusia harus dapat menggunakan serta memanfaatkan waktu dengan sebaik mungkin, sehingga ketika manusia dapat mengatur waktu dengan baik maka kedisiplinan akan menjadi hidup kita menjadi lebih teratur, prinsip hidup yang terarah, teguh dalam berjuang meraih cita - cita sehingga dapat mencapai kesejahteraan hidup. Pada umumnya sebenarnya sifat kedisiplinan yang dijalankan secara teratur dalam kehidupan dapat akan membawa dampak yang signifikan terhadap akhlak dan tingkah laku individu pada kegiatannya. ${ }^{4}$

Dalam kehidupan santri di pesantren, perilaku disisplin sangat rutin dijalankan dalam beberapa kegiatan rutin yang dijadwalkan seperti sholat berjama'ah, membaca al-qur'an, membaca kitab, bersih-bersih kamar, dan lain-lain. Semua kegiatan tersebut diatur dengan jadwal yang telah ditentukan dan sifatnya wajib diikuti oleh semua penghuni pesantren yang dengan hal

\footnotetext{
${ }^{1}$ Moh Shocib, Pola Asuh Orang Tua dalam Membentuk Disiplin Diri (Jakarta: Rineka Cipta, 1998), hal. 12.

${ }^{2}$ Sugeng Haryono, Pengaruh Kedisiplinan Siswa dan Motivasi Belajar Terhadap Prestasi Belajar Siswa pada Mata Pelajaran Ekonomi (Faktor Jurnal Ilmiah Kependidikan, Vol.3, No.3), Hal.264

${ }^{3}$ Aisyah, Al-qur'an dan Terjemah untuk wanita, hal.601

${ }^{4}$ Lilly Dwi Wulandari. Pengaruh kedisiplinan terhadap Prestasi Belajar Siswa Mata Pelajaran
} Ekonomi Kelas XI Pada Siswa SMA Negri 4 Depok (Jurnal Pendidikan Unsika. 2017). Vol.5, No.2, hal.149

Al Qalam: Jurnal Ilmiah Keagamaan dan Kemasyarakatan Vol. 16, No. 2 Maret - April 2022 
Alif Achadah, Fina Faza Rohmah : Implementasi Kegiatan Sholat Tahajud Dalam Meningkatkan Kedisiplinan Santri di Pondok Pesantren Putri Basussalam Banjarejo Pagelaran Malang

tersebut kedisiplinan santri akan terasah sehingga menjadi kebiasaan. Salah satu sikap kedisiplinan yang dikembangkan di pesantren ini adanya budaya sholat tahajjud yang awalnya mungkin terasa berat bagi snatri-santri baru tetapi akan menjadi kebiasaan yang merasa kurang jika ditinggalkan bagi santri - santri senior yang dalam lingkungan pesantren yang secara tidak langsung penerapan kegiatan sholat tahajjud tersebut merupakan salah satu proses kedisiplinan untuk mengajarkan pendidikan yang sebagai wujud proses perkembangan kemampuan dalam kegiatan nyata sebagai usaha mewujudkan kehidupan yang lebih baik. ${ }^{5}$

\section{METODE PENELITIAN}

Dalam penelitian ini menggunakan metode penelitian kualitatif dengan pendekatan fenomenologi. Penelitian kualitatif adalah penelitian yang data - data yang diperoleh dalam penelitian dituangkan dalam deskripsi cerita. Adapun fenomenologi adalah penelitian yang langsung mengambil data dari fenomena atau kenyataan langsung di lokasi penelitian. Dalam literatur lain disebutkan bahwa pendekatan fenomenologi adalah studi tentang pengetahuan yang bersumber dari kedasaran atau cara kita mendefinisikan suatu lokasi serta kejadian yang dapat dijadikan pengalaman peneliti secara nyata. ${ }^{6}$

Metode penelitian kualitatif adalah metode penelitian yang berlandaskan pada filsafat postpositivisme, digunakan untuk meneliti pada kondisi obyek yang alamiah, (sebagi lawannya adalah eksperimen) dimana peneliti adalah sebagi intrumen kunci, teknik pengumpulan datadilakukan secara triangulasi (gabungan), analisis data berupa induktif/ kualitatif, dan hasil penelitian kualitatif lebih menekankan makna dari pada generalisasi. ${ }^{7}$

Dalam penelitian kualitatif, kedudukan peneliti adalah sebagai pelaksana utama untuk mengumpulkan data, posisi peneliti juga sebagai pembuat rencana, pelaku pengumpulan data, memaparkan data yang didapat, dan menganalisis data yang diperoleh. ${ }^{8}$

Terkait sumber data dalam penelitian ini adalah obyek dimana peneliti mendapatkan informasi dan data untuk menjawab fokus penelitiannya. Adapun sumber data dalam penelitian ini ada sumber data primer dan sumber data sekunder. Sumber data dalam penelitian ini adalah subyek dari mana data dapat diperoleh, sumber data utama dalam penelitian kualitatif adalah kata-

5 Ahmad Taofik. Lembaga Pendidikan Islam di Indonesia Indonesia (Journal of Adult and Community Education.2020). Vol.02, No.2, hal.3

${ }^{6}$ Stephen W Littlejohn, Theories of Human Communication, (USA: Wadworth Publishing, 2000), hlm, 38 2017), hal.9

7 Sugiono, Metodologi Penelitian Kuantitatif, Kualitatif, dan R\&D, (Bandung: Penerbit Alfabeta,

${ }^{8}$ Lexy J. Maleong, Metodologi Penelitian Kualitatif, (Bandung: PT Remaja Rosdakarya, 2011), hal. 121

Al Qalam: Jurnal Ilmiah Keagamaan dan Kemasyarakatan Vol. 16, No. 2

Maret - April 2022 
Alif Achadah, Fina Faza Rohmah : Implementasi Kegiatan Sholat Tahajud Dalam Meningkatkan Kedisiplinan Santri di Pondok Pesantren Putri Basussalam Banjarejo Pagelaran Malang

kata dan tindakan. Selebihnya adalah data tambahan seperti dokumen dan lain-lainnya. ${ }^{9}$ Adapun untuk metode pengumpulan data menggunakan metode wawancara, observasi, dan dokumentasi.

\section{HASIL DAN PEMBAHASAN}

\section{A. Implementasi Kegiatan Sholat Tahajud Santri Asrama Tahfidzul Quran di Pondok}

\section{Pesantren Putri Babussalam Banjarejo Pagelaran Malang}

Implementasi dapat diartikan juga pelaksanaan atau penerapan. Dalam konteks ini akan diabahs terkait dengan implementasi kegiatan sholat tahajjut yang dilakukan olej santri yang ada di pondok pesantren putri Babussalam Banjarejo Pagelaran Malang. Adapun pelaksanaan kegiatan sholat tahajjut di pesantren ini telah menjadi kebiasaan yang dijadwalkan secara rutin sebagai salah satu cara untuk meningkatkan keimanan santri serta membentuk kedisiplinan santri.

Kegiatan sholat tahajjut dilakukan pada pukul 03.00 WIB yang dilakukan secara berjama'ah yang diimami oleh ustadzah yang telah menjadi pengurus di pesantren dan dilanjutkan dengan dzikir bersama sampai menunggu waktu sholat subuh. Kegiatan ini menjadi kegiatan rutin dan telah menjadi kebiasaan bagi santri di pondok pesantren ini sehingga melakukan kegiatan ini menjadi sebuah kebutuhan.

Hal lain yang juga menjadi tolak ukur kedisiplinan adalah kegiatan muroja'ah yang dilakukan oleh santri yang ada dalam program tahfidzul qur'an. Membaca al-qur'an selain merupakan suatu salah satu ibadah bagi umat Islam, di pesantren ini juga merupakan kebiasaan yang menjadi kewajiban bagi snatri dalam konteks untuk meningkatkan kedisiplinan santri. Kegiatan muroha'ah dilakukan secara berkelompok berdasarkan kamar santri yang terdiri dari 5 kelompok yang setiap kelompoknya terdiri dari 4 - 5 santri. Adapun tata cara dalam kegiatan muroja'ah ini dengan setiap santri membacakan ayat yang telah ditentukan oleh ustadzah dengan menggunakan metode bil-ghoib atau ayatan. Adapun metode ayatan adalah membaca ayat alqur'an dengan membaca setiap ayat secara bergantian.

Dengan metode tersebut ustadzah akan dapat memperhatikan serta mengetahui bacaan dari setiap santri sehingga ketika ada kesalahan bisa segera dibenahi dan target untuk mengahafal al-qur'an dengan baik dan benar akan dapat dilampaui oleh santri. Hal lain yang penting selain target menghafal al-qur'an adalah menanamkan snatri untuk menjadikan al-qur'an sumber hokum dan pedoman hidup dalam aktivitas sehari-hari.

Terkait dengan implementasi sholat tahajjut di Asrama Tahfidzul Qur'an Pondok Pesantren Putri Babussalam, ada petugas dan pengawas khusus untuk mengontrol pelaksanaan sholat tahajjut tersebut. Pengawas tersebut diambilkan dari ustadzah yang sudah menjadi

\footnotetext{
${ }^{9}$ Lexy J. Maleong, Metodologi, hal.157
}

Al Qalam: Jurnal Ilmiah Keagamaan dan Kemasyarakatan Vol. 16, No. 2 Maret - April 2022 
Alif Achadah, Fina Faza Rohmah : Implementasi Kegiatan Sholat Tahajud Dalam Meningkatkan Kedisiplinan Santri di Pondok Pesantren Putri Basussalam Banjarejo Pagelaran Malang

pengurus di asrama yang ustadzah tersebut mempunyai tugas untuk menertibkan dan memastikan bahwa semua santri mengikuti kegiatan sholat tahajjut. Koordinasi dengan setiap ketua kamar yang tekhnisnya adalah dengan adanya bel di 10 menit sebelum pelaksanaan sholat tahajjut yang bertujuan untuk mengingatkan santri bahwa waktu sholat tahajjut telah tiba. Bel selanjutnya akan dibunyikan 5 menit sebelumnya yang pada saat ini para pengawas akan mengontrol setiap kamar untuk memastikan bahwa semua santri telah bangun dan bersiap untuk melaksanakan sholat tahajjut.

\section{B. Implikasi Kegiatan Sholat Tahajud dalam Meningkatkan Kedisiplinan Santri Asrama Tahfidzul Quran Pondok Pesantren Putri Babussalam Banjarejo Pagelaran Malang}

Pelaksanaan sholat tahajjut menjadi sangat penting dan menjadi kegaiatn wajib yang harus dilakukan oleh snatri di pondok pesantren ini. Selain bertujuan untuk peningkatan keimanan, sholat tahajjut ini juga sebagai suatu cara untuk meningkatkan kedisiplinan santri sehingga dapat menjadi bekal dalam kehidupan di masyarakat. Adapun beberapa implikasi dari kegiatan sholat tahajjut yang dilakukan santri yaitu :

a. Meningkatnya keimanan kepada Allah SWT

Dalam proses pembiasaan sholat tahajjut berjama'ah, santri dituntut dan diwajibkan untuk melaksanakan kegiatan tersebut yang secara langsung berdampak positif bagi pribadi snatri itu sendiri. Dengan semakin mendekatkan diri kepada Allah otomatis keimanan serta kepercayaan kita sebagai umat beragama semakin meningkat dan semakin berserah kepada Sang Pencipta. Dalam sholat tahajjut ini santri benar-benar berpasrah diri, bertaubat atas segala kesalahan, dengan sepenuh hati menjalankan perintah dan menjauhi larangan-Nya.

b. Merasakan ketenangan dalam hati

Nikmat yang dirasakan setelah melaksanakan sholat tahajjut adalah merasakan ketenangan hati yang sangat dalam, bersyukur atas nikmat sehat yang diberikan oleh Allah SWT sehingga kita bisa menjalankan ibadah dengan sempurna dan hanya mengharap ridho dari-Nya. Dalam kegiatan sholat tahajjut ini dapat menjadi sarana bagi santri untuk mendekatkan diri kepada Allah dan juga menimbulkan rasa istiqomah dalam beribadah sehingga timbul ketenangan dalam hati,

c. Meningkatnya kedisiplinan terhadap waktu

Sebelum jam 03.00 pagi para santri dibangunkan untuk melaksanakan sholat tahajjut yang kebiasaan tersebut dapat melatih santri dalam disiplin waktu, waktu harus dipergunakan dengan sebaik-baiknya, menggunakan waktu untuk kepentingan dan kegiatan yang positif karena waktu yang sudah dilalui tidak dapat diputar kembali. Dalam lingkungan pesantren santri dibiasakan dengan kegiatan - kegiatan yang baik dan sangat menghargai waktu dengan melakukan kegiatan kegiatan positif

Al Qalam: Jurnal Ilmiah Keagamaan dan Kemasyarakatan Vol. 16, No. 2

Maret - April 2022 
Alif Achadah, Fina Faza Rohmah : Implementasi Kegiatan Sholat Tahajud Dalam Meningkatkan Kedisiplinan Santri di Pondok Pesantren Putri Basussalam Banjarejo Pagelaran Malang

d. Meingkatnya kedisiplinan dalam tingkah laku

Selain disiplin waktu, santri juga diajarkan untuk disiplin dalam tingkah laku seperti disiplin dalam berkata baik, sopan santun, tekun menjalankan ibadah, istiqomah dalam membaca alqur'an. Dengan kebiasaan dalam disiplin bertingkah laku akan membuat santri mempunyai kebiasaan baik dalam berperilaku dalam kegiatan sehari - hari.

e. Meningkatnya motivasi belajar santri

Belajar adalah salah satu aspek penting dalam kehidupan manusia dalam upaya untuk meningkatkan kesejahteraan hidup kita. Salah satu tempat untuk belajar adalah pondok pesantren sebagai salah satu tempat memperkaya dan menimba ilmu - ilmu agama. Bukan hanya pondok pesantren, sekolah juga merupakan salah satu tempat untuk menimba ilmu pengetahuan dan belajar. Intinya adalah dimanapun bisa dijadikan tempat untuk belajar dan motivasi akan belajar itulah yang harus dipupuk dan ditingkatkan. Dalam implementasi sholat tahajjut ini secara tidak langsung dapat meningkatkan motivasi santri dalam belaja dalam

\section{Faktor Pendukung dan Penghambat Pelaksanaan Kegiatan Shalat Tahajud di Asrama} Tahfidzul Quran Pondok Pesantren Putri Babussalam

1. Faktor Pendukung

a. Adanya keinginan yang sama antara pemilik pesantren, pengelola pesantren, wali santri, serta santri akan keinginan dalam penerapan kedisiplinan yang ada di lingkungan pesantren yang dalam hal ini adalah pembiasaan kegiatan sholat tahajjut secara berjama'ah

b. Adanya pemberian sanksi kepada santri yang melanggar peraturan yang telah di tetapkan di asrama. Sanksi dan hukuman ini bertujuan untuk memberikan pendidikan kepada santri agar disiplin dalam menjalankan peraturan yang ada sehingga mempunyai tanggung jawab yang penuh atas kewajibannya di asrama. Untuk mempermudah indentifikasi bagi santri yang melanggar peraturan maka ada laporan dari setiap ketua kamar disetiap minggunya sebagai bentuk tanggung jawab ketua atas tugas yang diberikan kepadanya. Adapun bentuk dari sanksi tersebut berupa kegiatan yang masih berhubungan dengan pendidikan seperti hafalan ayat - ayat al-qur'an atau kitab, membersihkan kamar maisng - masing atau halaman, dan lain - lain. Dengan adanya sanksi tersebut akan melatih santri untuk berfikir ketika akan melakukan kesalahan dan ada konsekuensi dari setiap perbuatan yang kita lakukan

c. Adanya pemberian penghargaan bagi santri yang berprestasi di asrama tahfidzul qur'an pondok pesantren putri babussalam yang dilakukan pada setiap akhir tahun bagi santri yang berprestasi dan hal ini dapat menjadi motivasi bagi santri untuk selalu meningkatkan kedisiplinannya.

2. Faktor Penghambat

Al Qalam: Jurnal Ilmiah Keagamaan dan Kemasyarakatan Vol. 16, No. 2

Maret - April 2022 
Alif Achadah, Fina Faza Rohmah : Implementasi Kegiatan Sholat Tahajud Dalam Meningkatkan Kedisiplinan Santri di Pondok Pesantren Putri Basussalam Banjarejo Pagelaran Malang

Yang termasuk factor penghambat dalam penerapan kedisiplinan yang lebih khusus dalam pembiasaan sholat tahajjut adalah terkait dengan bagaimana cara pengurus, ustadzah, ketua kamar untuk menanggulangi kemalasan pada diri santri. Kemalasan adalah masalah internal yang ada dalam diri santri sehingga perlu diperangi dan dilawan oleh santri itu sendiri untuk kemalasan tersebut. Ketika kemalasan tersebut masih ada di dalam diri santri maka dampak lain yang timbul adalah kurang aktifnya santri dalam kegiatan asrama. Untuk menanggulangi masalah tersebut maka ustadzah pengurus dan ketua kamar secara sabar dan terus menerus memberikan motivasi kepada santri untuk aktif dalam keikutsertaan dalam kegiatan asrama.

\section{KESIMPULAN}

1. Implementasi kegiatan pembiasaan melalui sholat tahajjut yang ada di Asrama Tahfidzul Qur'an Pondok Pesantren Putri Babussalam bisa dilaksanakan dengan maksimal dan hampir semua santri aktif dalam mengikuti kegiatan tersebut. Adapun kegiatan sholat tahajjut tersebut dimulai pada ham 03.00 WIB dan dilanjutkan dengan dzikir bersama sampai menunggu adzan saat sholat subuh. Kegiatan tersebut rutin dilaksanakan dalam rangka menigkatkan kedisiplinan santri di asarama

2. Adapun implikasi dalam penerapan sholat tahajjut berjama'ah ini dapatmeningkatkan keimanan kepada Allah SWT, meningkatkan kedisiplinan santri, meningkatkan ketenangan hati, meningkatkan disiplin dalam waktu, meningkatkan disiplin tingkah laku, dan meningkatkan motivasi belajar santri.

\section{DAFTAR PUSTAKA}

Agustian, Ary Ginanjar. 2001. Rahasia Sukses Membangun Kecerdasan Emosi dan Spritual (ESQ). jakarta: Arga Wijaya Persada.

Ahmed Erkan, Ahmad. 2016. 4 Shalat Dasyat, Jakarta: Keysa Media.

Andiawan, Didik. 2017. Dikejar Rizki Karena Sholat Malam, Yogyakarta: Albi

Dian Hutami, Dian. 2020. Pendidikan Karakter Untuk Anak: Disiplin dan Kerja Keras, Jogjakata: Cosmic Media Nusantara.

Haryono, Sugeng. Pengaruh Kedisiplinan Siswa dan Motivasi Belajar Terhadap Prestasi Belajar Siswa pada Mata Pelajaran Ekonomi (Faktor Jurnal Ilmiah Kependidikan)

Imron, Ali. 2016. Manajemen Peserta Didik Berbasis Sekolah. Jakarta: Bumi Aksara

Maleong, Lexy J. 2011. Metodologi Penelitian Kualitatif, Bandung: PT Remaja Rosdakarya

Malik, Muhammad Rusli. 2003. Puasa; Menyelami arti Kecerdasan Spiiritual dan Kecerdasan Emosional di Bulan Ramadhan. Jakarta: Pustaka Zahra

Manan, Abdul. 2006. Rahasia Shalat Sunnah, Bandung: Pustaka Hidayah

Moh Syamsi Hasan. 2008. Terjemah Durotun Nasihin. Surabaya: Amelia

Muhammad. 2010. Mukjizat Sholat Tahajud. Darul Taqwa Lil’Ulum: Damaskus

Al Qalam: Jurnal Ilmiah Keagamaan dan Kemasyarakatan Vol. 16, No. 2

Maret - April 2022 
Alif Achadah, Fina Faza Rohmah : Implementasi Kegiatan Sholat Tahajud Dalam Meningkatkan Kedisiplinan Santri di Pondok Pesantren Putri Basussalam Banjarejo Pagelaran Malang

Muhyidin, Muhammad. 2013. Misteri Sholat Tahajud. DIVA Press: Banguntapan Jogjakarta

Mukhammad Maskub, Mukhammad. 2016. Tuntunan Shalat wajib dan sunat 'Ala Aswaja, Kebumen, Pustaka Baru Pres

Al Qalam: Jurnal Ilmiah Keagamaan dan Kemasyarakatan Vol. 16, No. 2

Maret - April 2022 